Violence prevention and health promotion

\section{Prevenção da violência e promoção da saúde}

Olga M aria Bastos ${ }^{3}$

The authors choose a convenient moment for bringing up the discussion of a subject rarely presented in theliterature: violenceagainst peoplewith disability. The article fits well with the recommendations of the Brazilian Policy of Reduction of M orbidity/M ortality by Accidents and $V$ iolence ${ }^{1}$, which introduced theissue of violence in connection with health promotion. The expansion of the issue of violence, now related to a national public policy, is an important strategy in the attempt to reduce impairments resulting from violence in its different forms. The focus of the article, providing insight into the scenarios that allow for understanding the association between poverty, disability and violence, make it of huge importance. It also adds to the to the prescriptionsfor reducing maltreatment against peoplewith disabilities.

Although the authors comefrom countries very different from each other (Brazil and the United States), they revealed similar experiences and reinforced that therearesimilarities between developed and under-developed countries. Cavalcante \& Goldson, independently, have done important work in the disability field and, through the opportunity of the International Seminar organized by Fiocruz, referred to in the paper, they combined their experiences for contributing to the dissemination of knowledge concerning the issue of violence against people with disabilities.

TheWorld Health Organization ${ }^{2}$ has made important contributions to the question of violence through the concept of an "ecological model." The model points out the multifaceted nature of violence, resulting from the interaction of individual, relational, social and cultural factors in historical contexts. The prevention of violence depends on how each of these factors relates to the other ${ }^{2}$. Although Cavalcante \& Goldson's article does not speak directly about theecological model, they make references to each one of the factors included in the model (from the individual to cultural factors).

The presentation of the article's discussion is interesting, beginning with questions related to society, poverty in Latin America and the Caribbean among all disadvantaged groups in the region. The authors address inequalities, social exclusion and iniquities, especially the lack of access to health services and education. They describe the impact of poverty on families, growing worth when there is a disabled person to be taken care of. The importance of adequate support, especially social support for families is recognized by the authors, given that this support influences the reversion of the cycle of poverty - violence- disability.

As a physician caring for adolescents, I ask for special attention to the group of intellectually impaired individuals because of the kinds of stress and embarrassment their families experience. The challenge of adolescence for an intellectually impaired person needs to be considered by parents, educators and adults in general. So, an adolescent
${ }^{3}$ Instituto Fernandes Figueira, Fundação Oswaldo Cruz. olgab@iff.fiocruz.br 
with an intellectual impairment or other disability needs to develop his/her own personal activities, achieve his/her sexual development and independence. Frequently there is a discrepancy between physical and emotional development as well as differences in social expectations. Adults may not understand the developmental process and may be angry or aggressive toward an adolescent with a disability, especially in relation to sexual behavior. Individuals with disabilities need to learn about sexuality just like typical developing adolescents. Thechanges that take placein adolescencefrequently are not understood or accepted by the caretakers. This is especially the case among intellectually disabled adolescents, making them more vulnerable to maltreatment ${ }^{3}$.

The proposal of an agenda for thefield of mental health and disability is put forth vigorously by Cavalcante \& Goldson. In Brazil, even with the important work done by the Coordenadoria $\mathrm{Na}$ cional para Pessoas Portadoras de Deficiência CORDE, 1986, (National Coordination for Persons with Disabilities) and by the Conselho $\mathrm{Na}$ cional dos Direitos das Pessoas Portadoras de D eficiência - CONADEM 1999, (National Council on the Rights of People with Disability), there is no agenda that deals with the complexity of the issue of disability, violence and poverty. Currently, what is needed is the development and implementation of new public policies in addition to the current ones, which is recommended in the article.

\section{References}

1. Brasil. M inistério da Saúde. Portaria no 737/2001. Institui a Política Nacional de Redução da M orbimortalidade por Acidentes e Violências. Diário Oficial da União 2001; 18 mai.

2. World Health Organization. World Report on Violence and Health. Geneva: WHO; 2002.

3. Bastos OM. Entre o desejo e o medo de ver o filho adolescer: narrativas de adolescentes com deficiência mental [tese]. Rio de Janeiro (RJ): Instituto Fernandes Figueira, Fundação Oswaldo Cruz; 2005. 